F. C. Ford Robertson of Oxford, England, has resigned as director of the Commonwealth Forestry Bureau and became, effective December 1, 1964, director-editor of the English-language portion of the Multilingual Forestry Terminology Project.

The project on which Ford Robertson is working is being administered by the Society of American Foresters. It is a cooperative arrangement with the Joint Committee on Bibliography and Terminology of the Food and Agriculture Organization of the United Nations and the International Union of Forest Research Organizations.

Through the SAF Committee on International Relations (V. L. Harper, chairman) a proposal was made to FAO and IUFRO which resulted in combined financial sponsorship of the project by the Governments of Canada and the United States. It is estimated that the cost will be $\$ 20,000$ annually for a period of 5 years. Because the Society of American Foresters is a nonprofit scientific organization it is possible for the Society to accept the financial contributions of the governments and administer the completion of the English-language portion of the project.

The terminology, when completed in English, will probably contain not less than 7000 terms and definitions. Its publication by the SAF will, it is expected, be followed by translations in other languages.

Ford Robertson's office is in the Forestry Building, South Parks Road, Oxford.

\title{
UNIVERSITY OF TORONTO AWARDS
}

To J. J. M. Nicholson, the Kimberly-Clark fellowship in silviculture, $\$ 2,000$.

To David W. Wild, a Forestry Memorial Scholarship, for best standing in Ontario Grade XIII examinations, \$350.

To E. S. Kondo, the Canadian National Sportsmen's Show fellowship in forest pathology, $\$ 1,500$.

To G. Michael Bonnor, the Forest Economics fellowship, $\$ 1,800$.

\section{North American Forest SoIls Conference}

The Joint Committee on Co-Sponsorship of North American Forest Soils Conferences, representing the Soil Science Society of America, Society of American Foresters, Canadian Society of Soil Science and the Canadian Institute of Forestry is pleased to announce that North Carolina State University at Raleigh, North Carolina has been chosen as the host institution for the Third North American Forest Soils Conference to be held in 1968. Dr. T. E. Maki, Chairman of the Department of Forest Management and Dr. C. B. Davey, Associate Professor of Forest Soils in the Soils Department will work together with Dean R. S. Preston of the School of Forestry and Dr. R. J. McCracken, Head of the Soils Department in the overall planning for the Conference.

The North American Forest Soils Conferences were initiated to provide a forum where foresters and soil scientists could meet periodically to present and discuss information of interest to both disciplines. They are held every five years. The first conference was held at Michigan State University in 1958 
and the second at Oregon State University in 1963. The host institution publishes the proceedings of the Conference.

\section{Editor's Note}

The above information was provided by K. A. Armson, Associate Professor of Forestry, Univ. of Toronto, who has replaced Dr. J. S. Rowe as CIF representative to the NAFSC Committee.

\section{Association of B.C. Registered Foresters}

Robert S. Wood, Vancouver, manager of timber planning for Weldwood of Canada, was elected president of the Association of B.C. Registered Foresters at the 18th annual meeting held in Prince George February 4 and 5. He succeeds Raymond R. Lejeune, Canada department of forestry, Victoria, who remains on the 1965 Council.

Elected vice president was W. Edward L. Young, B.C. forest service, Victoria. Also elected to the Council were Robert E. Breadon, director of the U.B.C. research forest; William G. Bishop, B.C. forest service, Prince Rupert; Tom R. Hubbard, B.C. forest service, Nelson; Donald W. Smith, forestry consultant, Victoria; and Fred T. Stinson, timber department manager, Federated Cooperative Limited, Canoe.

F. M. Knapp, Vancouver, was re-appointed registrar.

The meeting passed a resolution urging Council and members to adopt the abbreviation RPF, for registered professional forester. A full day was spent in workshop discussions of education for, and practice of, professional forestry in British Columbia.

\section{Annual Meeting of the Permanent Committee of I.U.F.R.O. IN TURKEY, 1964}

The Permanent Committee of the International Union of Forest Research Organizations held its 1964 meeting in Turkey, September 17th to 26th. Formal sessions were held in the University of Istanbul September 17th, 18th and 19th. The Faculty of Forestry of the University of Istanbul and the Directorate of Forestry for Turkey arranged a tour of forestry in northwestern Turkey for September 20th to 26th.

The tour lasted seven days and was spent examining teaching and research facilities, forest management projects, and logging operations throughout the northwest mountains of Turkey, and projects on erosion control and shelterbelt research on the Steppes near Ankara.

Turkey lies between $36^{\circ}$ and $42^{\circ}$ north latitude and $26^{\circ}$ and $55^{\circ}$ east longitude; $97 \%$ of the area lies in Asia. The total area is 296,503 sq. miles (including water) and the population is about 30 million. The most readily available description of Turkish forests published in English is that in Unasylva 6 (3), 1952. I have drawn freely from this for statistics. Approximately 13\% of the area or $38,400 \mathrm{sq}$. miles is classified as forest land. This is subdivided according to forest cover as follows: good high forest 4,000 sq. miles, productive coppice (mainly oaks) 10,000 sq. miles, and the remainder as degraded high forest (over 20,000 sq. miles) and very poor coppice. Only about 100 sq. miles of the forested area is privately owned.

Half of the growing stock is conifers and on some of the higher steep and inaccessible slopes there are excellent stands of pines, spruce, and firs. 